\title{
Effect of amikacin, cephalothin, clindamycin and vancomycin on in vitro fibroblast growth
}

\author{
Fernanda Timm Seabra Souza, Alexandre Silva de Mello, Kristiane Michelin and Janice Carneiro Coelho \\ Universidade Federal do Rio Grande do Sul, Departamento de Bioquímica Serviço de Genética Médica, \\ Hospital de Clínicas de Porto Alegre, Porto Alegre, RS, Brazil.
}

\begin{abstract}
The effect of four antibiotics (amikacin, clindamycin, cephalothin and vancomycin) was investigated considering that bacterial infection in fibroblasts cultures is a very frequent event. The investigation included the effect of the antibiotics on fibroblast growth and on the activity of the enzyme glucocerebrosidase. The antibiotics were added to the fibroblast cultures and cell growth was evaluated by counting the number of cells and their viability. After cell harvesting, the enzyme activity and content of protein were measured. The results allowed us to conclude that none of the antibiotics affected the cellular number nor the cellular viability. The content of protein decreased when cephalothin and clindamycin were added to the cultures, and glucocerebrosidase was affected in the presence of amikacin. Vancomycin did not interfere with any of the parameters analyzed, so it was chosen to be used in cell cultures to prevent the contamination by gram positive bacteria.
\end{abstract}

Key words: amikacin, cephalothin, clindamycin, vancomycin, fibroblasts, cell culture.

Received: April 30, 2003; Accepted: April 26, 2004.

\section{Introduction}

Bacterial contamination is a common event in laboratories that deal with culture of tissues. Often these problems are related to inadequate handling, washing and sterilization of the material as well as contamination of the culture medium, serum, and reagents (Freshney, 2000).

Our laboratory is located inside a university hospital and cultivates fibroblasts from skin biopsy, chorionic villus and amniocytes, which are obtained from patients with a high risk for inborn errors of metabolism. The diagnosis of these diseases is performed by enzymatic analysis of these materials. Although the fibroblasts are cultured in a carefully sterilized and clean environment, the contamination of one or several cultures sometimes occurs. This is a very serious event, since some samples will not be able to be recollected because many patients live in distant locations or have already died.

Fibroblasts cultures from skin biopsy are the most affected by bacterial and fungal contamination. In the last ten years, approximately $20 \%$ of all cultures have been contaminated, resulting in a significant loss of material and time. Consequently, in these cases, the diagnosis could not

Send correspondence to Janice C. Coelho, PhD. Hospital de Clínicas de Porto Alegre, Serviço de Genética Médica, Rua Ramiro Barcelos 2350, 90035-003 Porto Alegre, RS, Brazil. E-mail: jcoelho@ hcpa.ufrgs.br. be made, causing several problems for patients and their families.

When we find bacteria in a fibroblast culture, we always discharge the contaminated material in order to avoid further contamination of healthy cultures.

The bacteria found in fibroblast cultures belong to gram-negative and gram-positive groups, which means there is a wide spectrum of antibiotics capable of preventing the infection efficiently (Russell, 1998).

There is no mention in the literature concerning the effect of antibiotics on fibroblast growth and metabolism; only penicillin, gentamicin and amikacin are quoted by the manufacturers of culture media as preventing bacteria contamination. According to these manufacturers, these antibiotics can prevent and eliminate the bacteria and do not interfere with fibroblasts metabolism and morphology. Although these three antibiotics have been recommended, they do not prevent the whole spectrum of bacteria. Even though we can choose a specific antibiotic for a specific bacteria, we must face the fact that the dose of the drug, more often than not, is ineffective.

We still do not know what is the real effect of antibiotics on fibroblasts cultures. If these compounds act on cellular reproduction, they would affect fibroblast growth and development and consequently damage the enzymatic analysis to be performed later. 
The aim of this study was to evaluate the effect of four antibiotics (amikacin, clindamycin, cephalothin and vancomycin) on fibroblast cultures and the possibility of introducing their use in the culture laboratory routine. The introduction of these drugs in fibroblast cultures would prevent the bacterial contamination of these cells, avoiding loss of material and harm to patients.

\section{Material and Methods}

\section{Cell culture}

Skin fragments from 20 different patients were collected under absolutely aseptic conditions and immediately transferred to sterile Petri dishes containing HAM-F10 cell culture medium plus $20 \%$ fetal calf serum. These fragments were cut into several pieces (explants). The explants were transferred to the polystyrene cell culture flask Falcon T25 type containing HAM-F10 cell culture medium plus $20 \%$ fetal calf serum. When cells from the explants presented adequate growth, fibroblasts were detached from the bottom of the flask with $0.25 \%$ trypsin-EDTA solution and transferred to two new sterile flasks containing HAM-F10 cell culture medium plus $10 \%$ fetal calf serum. The cultures were kept in an incubator at $37{ }^{\circ} \mathrm{C}$ (Coelho and Giugliani, 2000). This procedure was repeated until we obtained a sufficient number of flasks for the addition of antibiotic. All participants signed an informed consent and our study was approved by the Ethics and Scientific Committee of Hospital de Clínicas de Porto Alegre.

After antibiotic addition, the cells were counted and submitted to viability tests. The fibroblasts were then removed from the flask with trypsin-EDTA solution and washed three times with PBS buffer. After centrifugation, the pellet containing the cells was kept frozen at $-40{ }^{\circ} \mathrm{C}$ until protein content determination (Lowry et al., 1951) and assay of enzyme activity.

\section{Antibiotic addition}

Amikacin $250 \mathrm{mg} / \mathrm{mL}$ was added to cultured fibroblasts at a final concentration of 11,22 and $33 \mu \mathrm{g} / \mathrm{mL}$; cephalothin $250 \mathrm{mg} / \mathrm{mL}$ was added to cultured fibroblasts at a final concentration of $1.5,3$ and $4.5 \mu \mathrm{g} / \mathrm{mL}$; clindamycin $198 \mathrm{mg} / \mathrm{mL}$ was added to cultured fibroblasts at a final concentration of 1,2 and $3 \mu \mathrm{g} / \mathrm{mL}$ and vancomycin $50 \mathrm{mg} / \mathrm{mL}$ was added to cultured fibroblasts at a final concentration of 2,4 and $6 \mu \mathrm{g} / \mathrm{mL}$. All concentrations used were higher than the minimum inhibitory concentration (MIC) of antibiotics studied and used against the majority of microorganisms encountered in a hospital environment (Goodman and Gilman, 1996). In all experiments we used a control culture without antibiotic. The cultures were incubated with the antibiotic at $37^{\circ} \mathrm{C}$ for 10 days.

\section{Photograph}

All cultures were photographed before and after the antibiotic addition in an inverted microscope Nikon Diaphot with Kodak Ektachrome film.

\section{Cell count and viability test}

Cells were counted microscopically after the antibiotic addition (day 10), using a hemocytometer. Cellular viability was measured by the trypan blue method (Cellis and Cellis, 1998) dividing the number of viable cells by the total number of cells (viable and dead).

\section{Enzyme assay}

$\beta$-glucocerebrosidase activity was determined by the method of Peters et al. (1976) using 4-methylumbelliferyl$\beta$-D-glucopyranoside as a substrate. The assay mixture contained $200 \mu \mathrm{L}$ of substrate dissolved in distillated water at a concentration of $10 \mathrm{mM}, 100 \mu \mathrm{L}$ of $0.54 \mathrm{M}$ citratephosphate buffer, $\mathrm{pH} 5.5$, and $40 \mu \mathrm{L}$ of fibroblasts (10-20 $\mu \mathrm{g}$ of protein) previously diluted in $0.9 \%$ sodium chloride. The incubation was at $37^{\circ} \mathrm{C}$ for $1 \mathrm{~h}$. The reaction was stopped with $3 \mathrm{~mL}$ of $0.5 \mathrm{M}$ glycine-sodium hydroxide buffer, $\mathrm{pH} 10.3$, and the fluorescence was read in a Hitachi F-2000 spectrofluorometer (excitation and emission wavelength of 365 and $450 \mathrm{~nm}$, respectively).

\section{Statistical analysis}

Data are reported as mean $\pm \mathrm{SD}$. The comparison among treatments using three distinct antibiotic concentrations and one without antibiotic culture was performed by one-way ANOVA followed by Tukey test whenever necessary. The Student $t$-test for unpaired samples was used to compare two groups. The analysis was performed using the statistical software package SPSS/PC+, version 3.0, and the level of significance was set at $\mathrm{p}<0.05$.

\section{Results}

The four antibiotics, in all the concentrations used, did not significantly increase or decrease the number of cells cultured (Table 1). Ten days after the antibiotics addition, the cells were photographed in order to observe their morphology and number. In figures 1 to 4 it can be seen that the quantity of cells did not change and this finding is in accordance with the results presented in Table 1. Moreover,

Table 1 - Effect of in vitro administration of amikacin, cephalothin, clindamycin and vancomycin on number of fibroblasts.

\begin{tabular}{lcccc}
\hline & amikacin & cephalothin & clindamycin & vancomycin \\
\hline $\begin{array}{l}\text { Without } \\
\text { antibiotic }\end{array}$ & $5.46 \pm 1.13$ & $6.57 \pm 1.33$ & $6.43 \pm 1.15$ & $7.83 \pm 0.35$ \\
C1 & $5.09 \pm 1.91$ & $8.42 \pm 1.73$ & $7.12 \pm 1.05$ & $7.17 \pm 0.76$ \\
C2 & $5.33 \pm 1.64$ & $9.14 \pm 3.63$ & $6.70 \pm 1.46$ & $7.02 \pm 1.06$ \\
C3 & $5.37 \pm 1.39$ & $7.62 \pm 2.02$ & $6.52 \pm 1.04$ & $6.49 \pm 1.46$ \\
\hline
\end{tabular}

Data are expressed as mean $\times 10^{5}$ cells \pm SD. All groups contain 5 fibroblasts cultures. Amikacin: $\mathrm{C} 1=11 \mu \mathrm{g} / \mathrm{mL}, \mathrm{C} 2=22 \mu \mathrm{g} / \mathrm{mL}$ and $\mathrm{C} 3=33 \mu \mathrm{g} / \mathrm{mL}$; cephalothin: $\mathrm{C} 1=1.5 \mu \mathrm{g} / \mathrm{mL}, \mathrm{C} 2=3 \mu \mathrm{g} / \mathrm{mL}$ and $\mathrm{C} 3=4.5 \mu \mathrm{g} / \mathrm{mL}$; clindamycin: $\mathrm{C} 1=1 \mu \mathrm{g} / \mathrm{mL}, \mathrm{C} 2=2 \mu \mathrm{g} / \mathrm{mL}$, $\mathrm{C} 3=3 \mu \mathrm{g} / \mathrm{mL}$; vancomycin: $\mathrm{C} 1=2 \mu \mathrm{g} / \mathrm{mL}, \mathrm{C} 2=4 \mu \mathrm{g} / \mathrm{mL}$ and $\mathrm{C} 3=6 \mu \mathrm{g} / \mathrm{mL}$. 
the morphology of the fibroblasts did not change after the addition of the four antibiotics (Figures 1 to 4 ).

Table 2 shows the results of the cellular viability test. As we can observe, there is no significant difference in fibroblast viability after antibiotic addition.

The content of protein in the cultures significantly decreased (Figure 5) when we added clindamycin $[\mathrm{F}(3,4)=22.99 ; \mathrm{p}<0.005]$ and cephalothin $[\mathrm{F}(3,4)=11.01$; $\mathrm{p}<0.02]$.

$\beta$-glucocerebrosidase activity increased in the presence of amikacin 22 and $33 \mu \mathrm{g} / \mathrm{mL}[\mathrm{F}(3,4)=21.49$; $\mathrm{p}<0.005]$ (Figure 6). The other antibiotics, in all concentrations used, did not alter the enzyme activity.

\section{Discussion}

We know that bacterial infection control in cell culture laboratories is a constant challenge and since the effect of antibiotics on fibroblasts growth, morphology, viability and metabolism is unknown, this study intended to evaluate the effect of four antibiotics, which act on a significant number of bacteria present in hospitals, on in vitro fibroblast cultures without bacterial contamination.

Penicillin, according to the literature, is the most commonly used antibiotic in fibroblast cultures. It can be used alone or with streptomycin or gentamicin, preventing
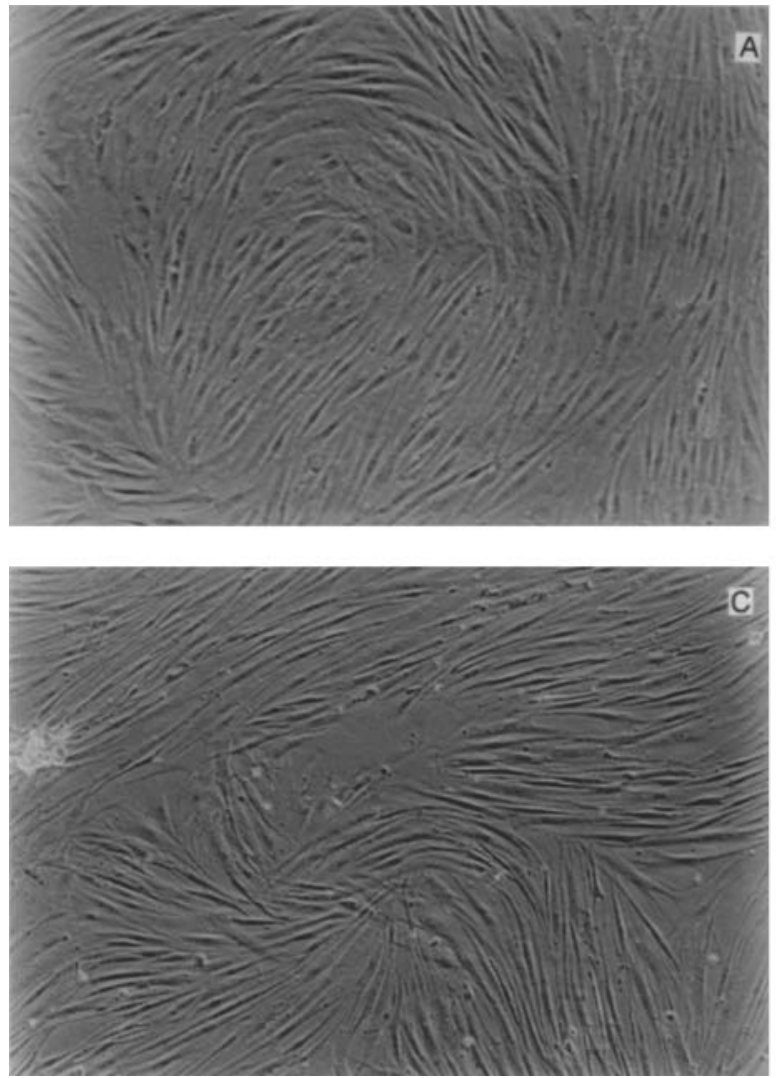

bacterial contamination, but their effects on fibroblasts seem unclear (Harrison and Rae, 1997).

In this study, we tested four other antibiotics: amikacin, clindamycin, cephalothin and vancomycin, which act either on gram-positive or in gram-negative bacteria. All concentrations used were superior to the minimum inhibitory concentration (MIC).

We began analyzing the fibroblast number and morphology. It can be observed that none of the antibiotics studied altered the number of cells in culture, inhibiting their growth, or their morphology. These results can be seen in the photographs and by the number of cells counted.

When we compare the fibroblast cultures before and after the antibiotic addition we can see that these compounds did not alter the cellular viability.

We observed that after cephalothin or clindamycin addition the number of cells remained the same, but there was a significant reduction in the cellular protein content. Maybe these substances are not acting on fibroblasts protein content, but interfering with the method of protein measurement used. According to Ludmil et al. (1993), several compounds can cause interference in the results when we use the Lowry et al. (1951) method to measure protein. This fact could have occurred in this study.

Even though these two antibiotics did not decrease the content of protein, they interfered in its measurement.
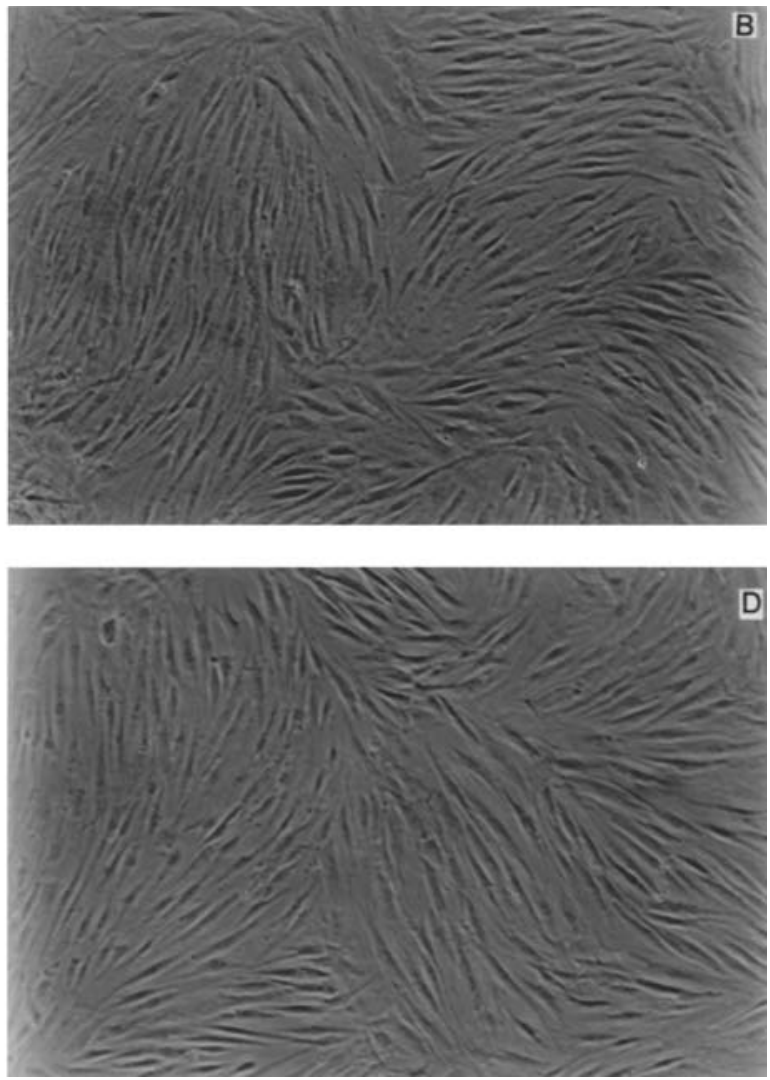

Figure 1 - Photograph of fibroblasts without (a) and after amikacin $11 \mu \mathrm{g} / \mathrm{mL}$ (b), $22 \mu \mathrm{g} / \mathrm{mL}$ (c) and $33 \mu \mathrm{g} / \mathrm{mL}$ (d) addition. (X 40). 

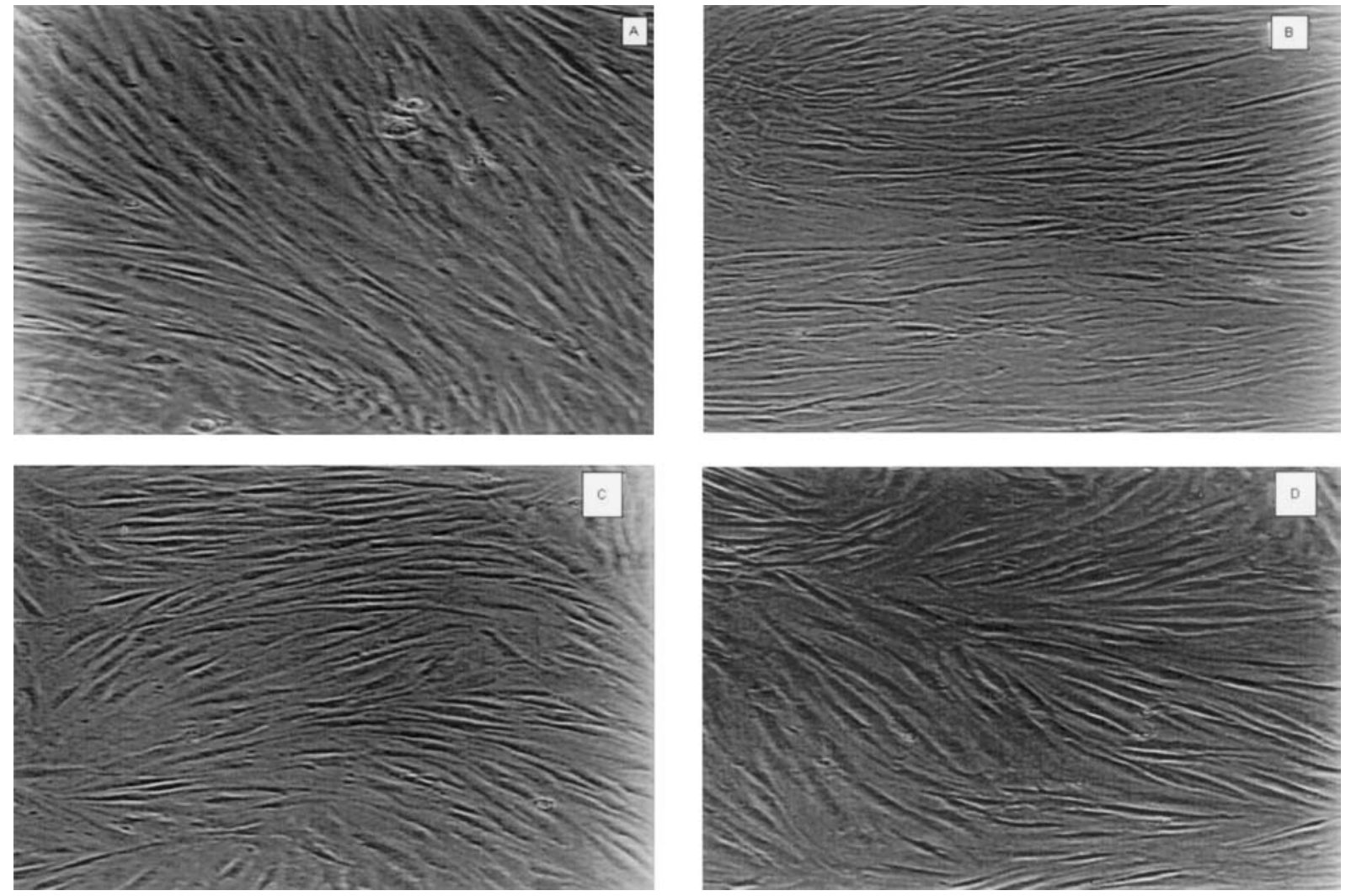

Figure 2 - Photograph of fibroblasts without (a) and after cephalothin $1.5 \mu \mathrm{g} / \mathrm{mL}$ (b), $3 \mu \mathrm{g} / \mathrm{mL}$ (c) and $4.5 \mu \mathrm{g} / \mathrm{mL}$ (d) addition. (X 40).
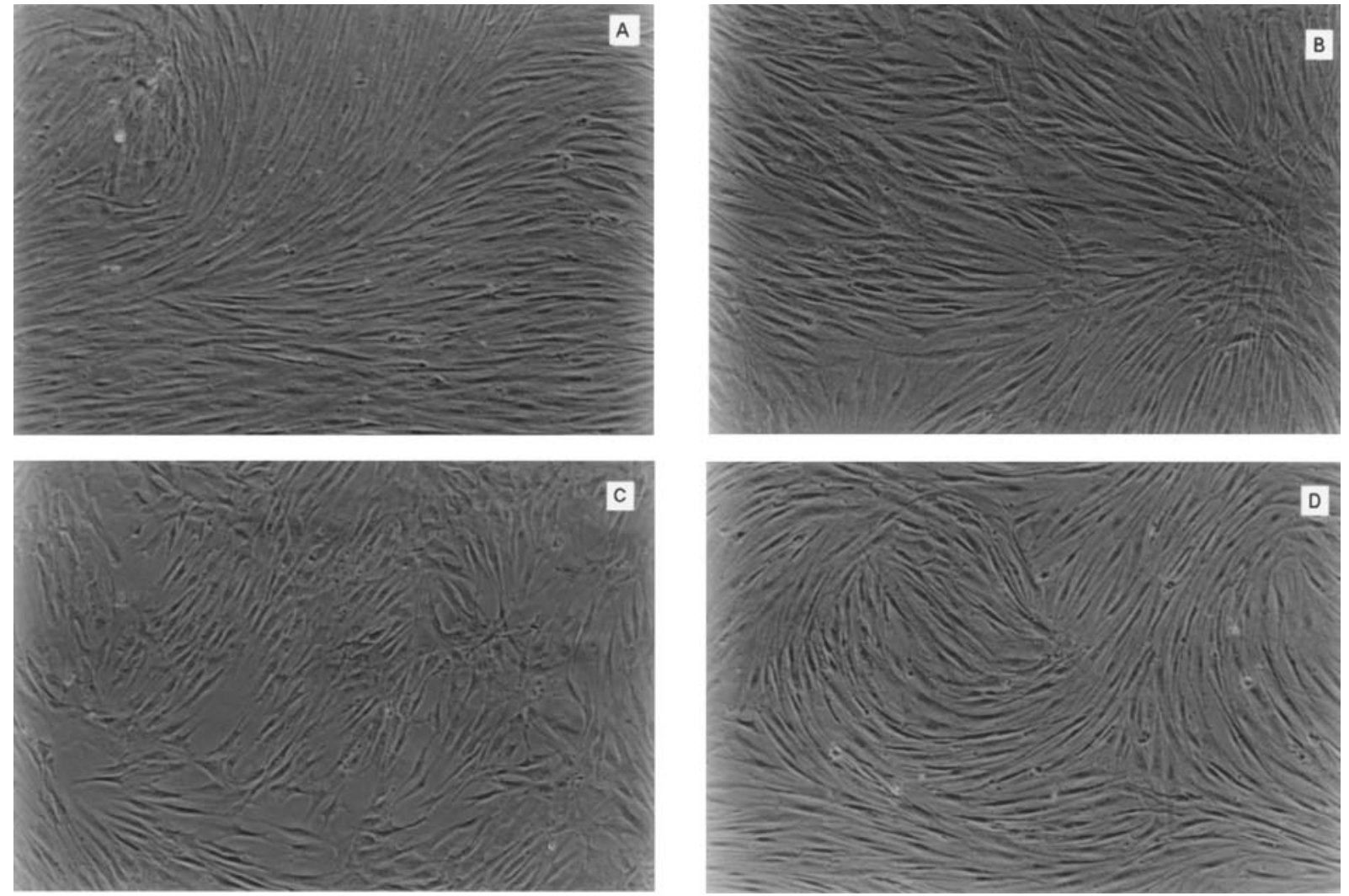

Figure 3 - Photograph of fibroblasts without (a) and after clindamycin $1 \mu \mathrm{g} / \mathrm{mL}$ (b), $2 \mu \mathrm{g} / \mathrm{mL}$ (c) and $3 \mu \mathrm{g} / \mathrm{mL}$ (d) addition. (X 40). 

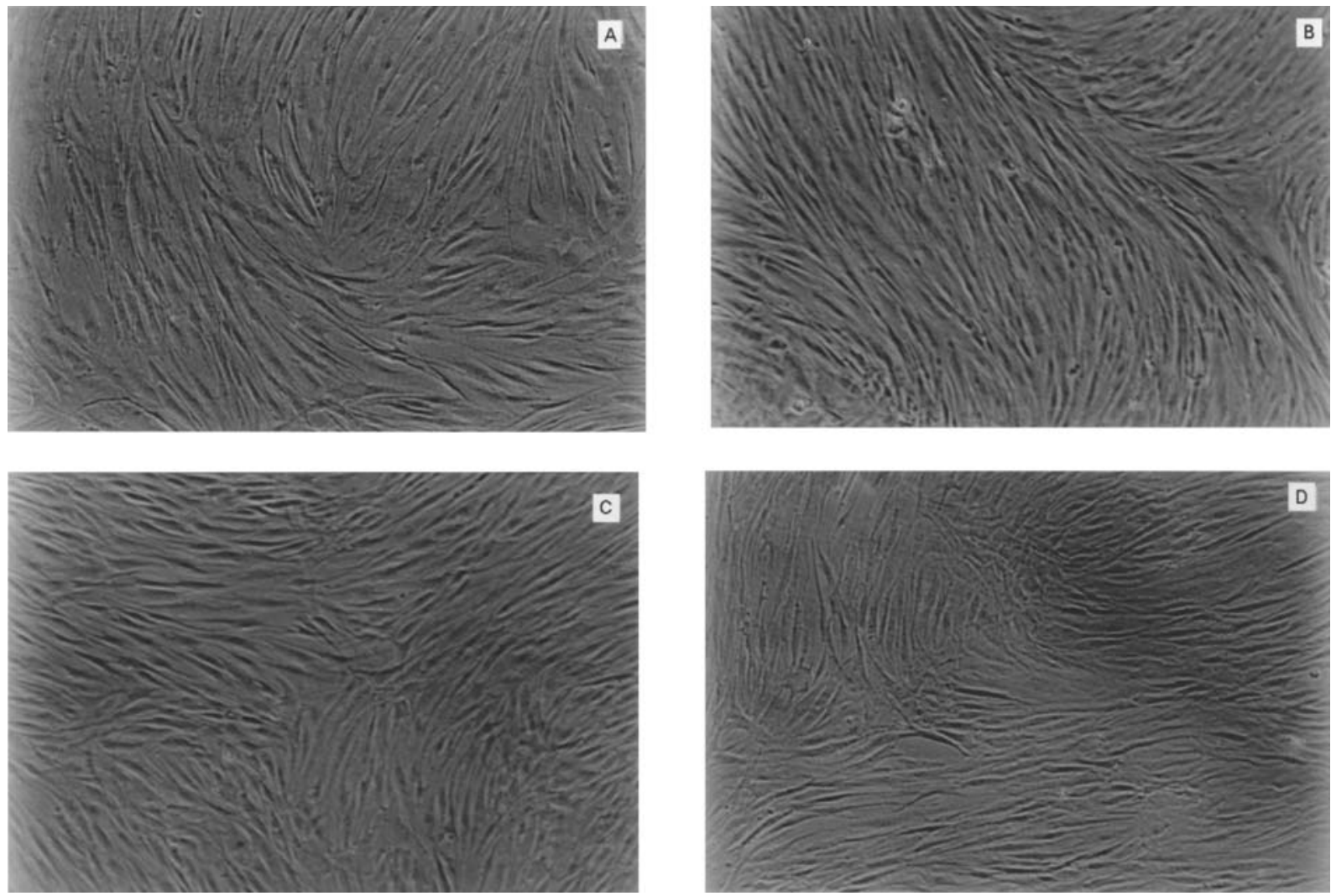

Figure 4 - Photograph of fibroblasts without (a) and after clindamycin $1 \mu \mathrm{g} / \mathrm{mL}$ (b), $2 \mu \mathrm{g} / \mathrm{mL}$ (c) and $3 \mu \mathrm{g} / \mathrm{mL}$ (d) addition. (X 40).

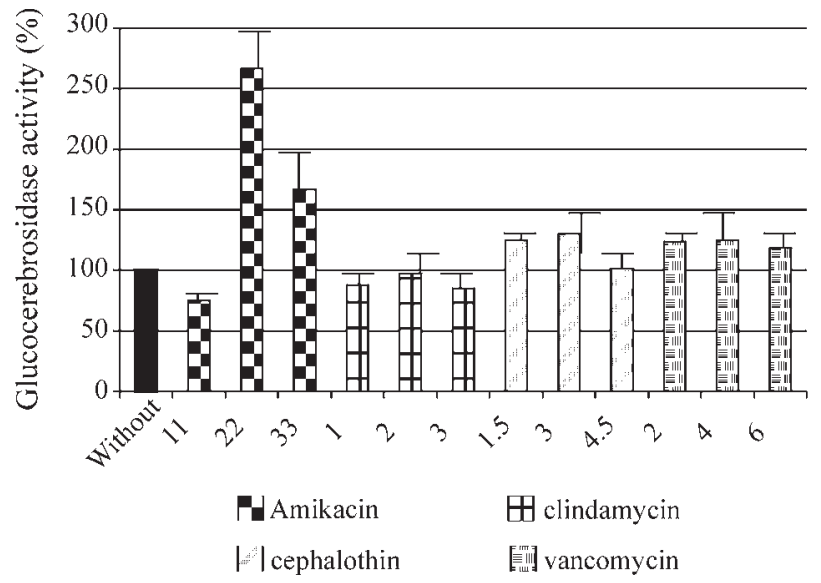

Figure 5 - Effect of antibiotics added to fibroblast cultures on its protein content. The results (mean $\pm \mathrm{SD}$ ) are expressed as $\%$ of protein content of cells that received antibiotics in relation to those without this drug $(100 \%)$. * statistical difference from $100 \%, \mathrm{p}<0.05$.

This can lead to erroneous results when we express the enzymatic activity by $\mathrm{mg}$ of protein.

Our group works with diagnosis and follow-up of lysosomal storage diseases, a group of inborn errors of metabolism. The most frequent of these diseases in our country is Gaucher Disease (Coelho et al., 2001). This disease is characterized by deficiency of glucocerebrosidase activity, which can be measured in leukocytes or fibroblasts. Be-

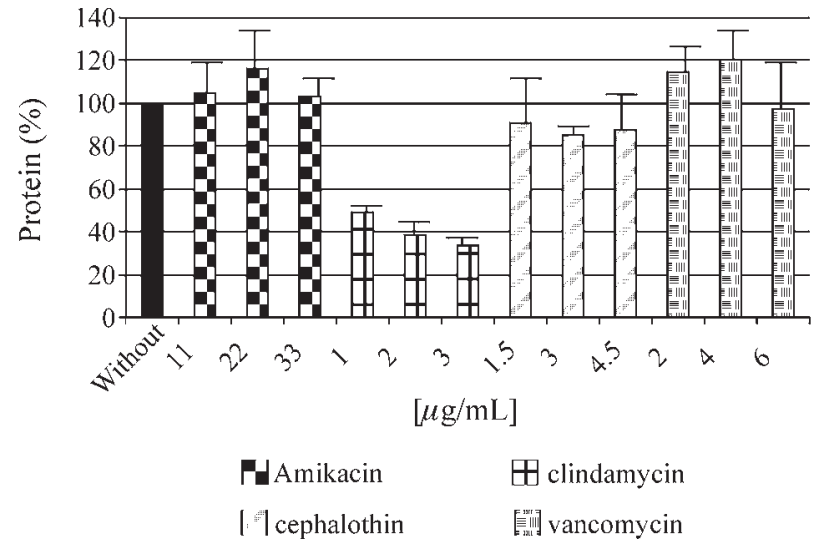

Figure 6 - Effect of antibiotics added to fibroblasts cultures on glucocerebrosidase activity. The results (mean $\pm \mathrm{SD}$ ) are expressed as $\%$ of enzyme activity of cells that received antibiotics in relation to those without this drug $(100 \%){ }^{*}$ statistical difference from $100 \%, \mathrm{p}<0.05$.

cause of this, we decided to choose glucocerebrosidase as the reference enzyme in this study.

Glucocerebrosidase activity in human fibroblasts varies from 350 to $1110 \mathrm{nmol} / \mathrm{h} / \mathrm{mg}$ of protein. As the range of activity is very wide and the number of samples in this study was very limited, we opted to express the results in percentage of enzyme activity. We compared the enzyme activity of control cells, which did not receive the antibiotic 
Table 2 - Effect of in vitro administration of amikacin, cephalothin, clindamycin and vancomycin on viability of fibroblasts.

\begin{tabular}{lcc}
\hline Antibiotic & Without antibiotic & With antibiotic \\
\hline amikacin $33 \mu \mathrm{g} / \mathrm{mL}$ & $50.00 \pm 2.26$ & $48.76 \pm 0.07$ \\
cephalothin $4.5 \mu \mathrm{g} / \mathrm{mL}$ & $72.60 \pm 3.60$ & $76.30 \pm 0.98$ \\
clidamycin $3 \mu \mathrm{g} / \mathrm{mL}$ & $71.20 \pm 6.50$ & $73.15 \pm 10.9$ \\
vancomycin $6 \mu \mathrm{g} / \mathrm{mL}$ & $54.55 \pm 3.60$ & $60.05 \pm 2.47$ \\
\hline
\end{tabular}

Data express the $\%$ of viable cells as mean \pm SD. All groups consisted of 5 fibroblast cultures.

$(100 \%)$, with the enzyme activity of cells that received one of the four antibiotics. This decreased the variability of data facilitating statistical analysis.

Our results showed that there was no difference in enzyme activity of control cells in relation to those that received clindamycin, cephalothin or vancomycin. When we added amikacin to the fibroblast cultures we observed that this antibiotic, at the concentration of $22 \mu \mathrm{g} / \mathrm{mL}$, increased glucocerebrosidase activity. In Gaucher Disease, the enzyme activity is very low. If amikacin is added to fibroblast cultures of these patients, we can observe an increase in glucocerebrosidase activity and this could be interpreted as if these patients were not affected.

The results obtained in this work show that it is possible to add an antibiotic, at least vancomycin, to fibroblast cultures in order to prevent bacterial infection without altering the number, protein content and glucocerebrosidase activity in these cells. This is in accordance with the observations of Dumontel et al. (1998), which described that vancomycin did not modify the activity of the enzyme sphingomyelinase, another lysosomal enzyme.

Vancomycin, which is an antibiotic that kills grampositive and gram-negative bacteria like Staphylococcus aureus and $S$. epidermidis, will help to avoid contamination, preventing loss of biological material.

Additional tests with other antibiotics and other enzymes and their activities should be measured in biochemical laboratories associated with cell culture labs. Amikacin could be a second option, since it did not interfere in other enzyme activities.

\section{Acknowledgements}

This study was supported by CNPq, GPPG/HCPA and PRONEX-MCT grant number 6610611997-3 (Brazilian Research Agencies).

\section{References}

Cellis A and Cellis JE (1998) General procedures for tissue culture. In: Cellis JE (ed) Cell Biology. Academic Press, New York, pp 5-15.

Coelho JC and Giugliani R (2000) Fibroblasts of skin fragments as a tool for the investigation of genetics diseases: technical recommendations. Gen Mol Biol 23:269-271.

Coelho JC, Burin M, Wajner M, Vargas CR, Souza FTS and Giugliani R (2001) Selective screening of 18,000 high risk Brazilian patients for the detection of inborn errors of metabolism. Rev HCPA 21:286:292.

Dumontel C, Constant H, Souillet G and Zabot MT (1998) In vitro toxic effects of certain antibiotics on the fibroblasts on two children with I-cell disease. Cell Biol Toxicol 14:333-343.

Freshney RI (2000) Culture of Animals Cells. A Manual of Basic Technique. $4^{\text {th }}$ ed. John Wiley, New York, $600 \mathrm{pp}$.

Goodman LS and Gilman AG (2001) The Pharmacological Basis of Therapeutics. $10^{\text {th }}$ ed. McGraw-Hill, New York, $1825 \mathrm{pp}$.

Harrison AH and Rae IF (1997) General Techniques of Cell Culture. University Press, Cambridge, $162 \mathrm{pp}$.

Lowry OH, Rosebrough NJ, Farr AL and Randall RJ (1951) Protein measurement with the folin phenol reagent. J Biol Chem 193:265-275.

Ludmil PK, Lubomir GV and Ewgeni PK (1993) Comparison of the Lowry and the Bradford Protein assays as applied for protein estimation of membrane-containing fractions. Anal Biochem 208:44-48.

Peters SP, Coyle P and Glew RH (1976) Differentiation of $\beta$ glucocerebrosidase from $\beta$-glucosidase in human tissues using sodium taurocholate. Arch Biochem Biophys 175:569571.

Russell AD (1998) Types of antibiotics and synthetic antimicrobial agents. In: Hugo WB and Russell AD (eds) Pharmaceutical Microbiology. $6^{\text {th }}$ ed. Blackwell Science Inc., Winnipeg, pp 91-129.

Associate Editor: Catarina S. Takahashi 